Federal Reserve Bank of Minneapolis

Research Department Working Paper

\title{
EFFECTS OF FEDERAL GRAIN PROGRAMS \\ ON THE LIVESTOCK SECTOR
}

Richard M. Todd

Working Paper 270

PACS File 4350

Revised April 1985

NOT FOR DISTRIBUTION

WITHOUT AUTHOR'S APPROVAL

The views expressed are those of the author and not necessarily those of the Federal Reserve Bank of Minneapolis or the Federal Reserve System. The material contained is of a preliminary nature, is circulated to stimulate discussion, and is not to be quoted without permission of the author. 


\begin{abstract}
Direct federal government intervention in the livestock sector (excluding the dairy and wool programs, which are not discussed in this paper) has not been common in recent years. With the important exception of beef import quotas, the federal government's influence on livestock prices and the incomes of livestock producers has mostly been indirect, through programs that affect the supply and price of crops. Even so, the potential indirect effects on the livestock sector of the federal grain programs are numerous and include changes in the quantity and mix of livestock products produced; the average price of livestock as well as the relative prices of the several livestock products; the variability of livestock prices and quantities; the organization of livestock production; and the level and variability of producers' income and well-being.

Determining the extent and even the direction of these effects is not easy, however, and economists of ten disagree about them. Economists' estimates of the effects are based on simplified replicas, or models, of the economy. The fact that all practical models omit some significant aspects of the livestock-feedgrains economy-such as details of meat production technology, consumers' demand, or livestock producers' decision making processes-helps explain why the effects are hard to estimate and thus why econornists disagree about them.

Studies of the effects of the grain programs on the livestock sector do agree on some points. Most find that the grain programs, including current programs, have raised average grain prices by at least 10 percent. Higher grain prices, most studies agree, restrict total livestock production, with common estimates showing that a sustained 10 percent increase in feed costs cuts production of poultry by 1 percent or less, of
\end{abstract}


total beef by 1-3 percent, and of pork by 0-6 percent. The cuts in livestock production are generally thought to lead to more than proportional increases in most livestock prices and thus to higher gross income for the livestock sector as a whole.

Economists do not agree about which types of livestock producers are helped or hurt the most by high feed prices. Several studies report that higher feed prices cause gross income to rise more for pork and poultry producers than for beef producers. Other studies find the opposite, and still others point out that large adjustments occur within the beef sector, as production generally shifts from fed to nonfed beef. A few studies of livestock producers' net incomes suggest that cow-calf producers are hurt the most by higher feed costs.

Several layers of uncertainty surround any conclusions about whether the grain programs have stabilized the livestock sector. Evidence that the grain programs have stabilized feed prices since the 1960 s is weak at best, and some economists claim that the opposite is true. The evidence is also contradictory on the degree to which feed price stability, if it were achieved, would stabilize livestock prices and quantities, with some studies finding little impact. Finally, there is very little evidence on whether stable feed prices would stabilize livestock producers' incomes.

Economists also disagree about the role of the grain programs in the massive restructuring of the livestock sector that has taken place in the last four decades. The programs probably shifted some resources, especially marginal land, from pasture to crop production. The prima facie argument that stable grain prices reduce risk and thereby encourage farmers to forgo mixed crop and livestock production in favor of farms specialized in one or the other has not been empirically validated and has met with some skepticism. 


\section{EFFECTS OF FEDERAL GRAIN PROGRAMS ON THE LIVESTOCK SECTOR}

Except for milk and wool, the federal government has exerted little direct control over th prices of most livestock products and the incomes of their producers over the last 35 years. With the important exception of the beef import quota system legislated in the 1970s, the federal government's influence on livestock prices and the incomes of livestock producers has mostly been indirect, through programs that affect the supply and price of crops. The potential effects on the livestock sector of the grain programs include changes in the quantity and mix of livestock products produced; the average price of livestock as well as the relative prices of the several livestock products; the variability of livestock prices and quantities; the organization of livestock production; and the level and variability of producers' income and well-being. Determining the extent and even the direction of these effects is not easy, however, and the numerous efforts to measure them have of ten contradicted each other. Most studies agree that the grain programs have raised the price of livestock feed, restricted total livestock production, and raised overall livestock prices, but researchers still disagree about the other potential effects of the grain programs.

\section{DEFINING THE EFFECTS OF GRAIN PROGRAMS ON THE LIVESTOCK SECTOR}

Perhaps the first step in understanding the effects of grain programs on the livestock sector is to specify what we mean by "grain programs" and by "the livestock sector." In addition, we will need some standards by which to measure the effects.

Construed broadly, the livestock sector includes not only the farms and ranches that produce animal products ranging from milk to mink 
but also the firms that supply the inputs and process and market the products and the consumers who use the final products. Here, however, the term "livestock sector" will generally refer to the more narrow group of firms that produce the leading nondairy animal products, mainly cattle (fed and nonfed), hogs, chicken, eggs, turkey, and lamb. Dairy is omitted because it is subject to its own federal programs and because these programs are discussed elsewhere. Even this definition is not yet narrow enough, for many firms that produce livestock also produce crops covered by the federal grain programs. Generally I will include only the livestock portion of these mixed crop-livestock firms in my concept of the livestock sector, which amounts to assuming that the livestock and crop enterprises of a mixed firm are independent. This assumption is often not realistic, but we cannot proceed very far without it.

Specifying what is meant by "grain programs" not only involves narrowing down the long list of federal policies that affect the markets for grain but also requires defining what a program or a policy is. The first part is the easier. I mainly discuss the programs whose primary purpose has been to control the supply and price of the crops that most directly affect the livestock sector. These crops include the main components of livestock feed (corn, sorghum, barley, oats, soybeans, and wheat) as well as crops that compete for agricultural resources either with the feed crops or with livestock production directly (mainly cotton). The crop programs of primary interest here are th price support loan program of the Commodity Credit Corporation (CCC), various direct price support or target price payment programs, various production control programs (allotments, Soil Bank, set aside, diversion), the Farmer-Owned Reserve Program (FORP) for grains, and the Disaster Payments Program (DPP). Some combination of these programs has been in effect since 1948 . 
Since the history of federal grain programs is well documented [see Cochrane and Ryan (1976) or Rasmussen and Baker (1979) and their references ], it may seem that these programs can be thought of as just the sequence of government actions and announcements (loan rates, diversion payments, target prices, etc.) that actually took place. This hindsight can be misleading, however, because it ignores the uncertainty over future grain policy actions that producers actually faced. In a dynamic industry like agriculture, where biological lags and large investments in fixed capital slow adjustments to unexpected events, current production decisions can affect a producer's livelihood for years to come. For that reason, producers consider not only current but also expected future policy actions when making current production decisions. To predict future policy actions, the producer must try to understand the rules or processes of government behavior that will determine future, as-yet-unannounced policy actions. From the producer's point of view, then, a policy (or a program) is a rule or process that, along with future economic conditions, will trigger specific future actions by the government. If we wish to understand the producer and the producer's well-being, then in general this must be our point of view as well. In some cases viewing policy as a rule instead of as a sequence of actions could turn out to make only a small difference, but we cannot simply assume this. So ideally we would define the rules that generated the observed policy actions as the grain programs we wish to study.

Studies of the effects of the grain programs have been hampered by the fact that the rules which governed postwar grain policy are only partially documented. This may seem odd, since the legislative record is available and has been summarized and interpreted [Cochrane and Ryan (1976), Rasmussen and Baker (1979)]. However, the legislative record is 
inadequate in at least three ways. First, the legislation governing the programs at any time generally was scheduled to expire within four years or less, so producers concerned with more distant policy actions would have been trying to fathom the underlying political processes that would shape future legislation. Second, even the existing laws were sometimes subject to revision ahead of schedule, depending on the state of the agricultural economy. Finally, the laws in existence at any time were vague and delegated to the Department of Agriculture much administrative discretion for determining the exact policy actions to be taken. These features made policy actions more flexible but less predictable. They also make it almost impossible to say exactly what grain policy has been in the United States. Faced with this difficulty, many researchers have either viewed the grain programs as defined by the historical record of policy actions or have analyzed short time periods governed by single pieces of legislation. Neither of these approaches is fully satisfactory, but each is typical of the many kinds of methodological compromises that have been made in studies of the effects of the grain programs on the livestock sector. I will consider an ideal approach--policy as the true underlying process that generated all the observed postwar policy actions--as well as the compromise approaches that various researchers have employed, as context permits.

If we can compromise enough to settle on working definitions of the livestock sector and the federal grain programs that have affected the livestock sector, then all we need to begin an investigation of the effects of grain programs on the livestock sector is a standard or criterion by which we can measure the effects. Ideally we would like a measure of the contribution that livestock production makes to the well-being, or welfare, of the people who produce livestock, and a few studies try to define and 
measure livestock producers' welfare [see Hallam (1983) for an example and a summary]. Some other studies measure the level or variability of net income from livestock production, which are related to producers' welfare but not always in ways we understand well. Probably most studies measure either livestock prices, livestock quantities, or livestock producers' gross incomes, which bear no necessary relationship to either producers' net income or welfare. Even though these measures don't tell us what we really want to know, they are still part of the answer to how the grain programs affect the livestock sector. I use all of the measureswelfare; net income; and prices, quantities, or gross income.

\section{WHAT CAN ECONOMISTS HOPE TO SAY ABOUT THESE EFFECTS?}

Economists attempt to measure the effects of government policies by constructing and manipulating simplified replicas of the economy, which are known as models. A model capable of accurately measuring all the effects of a given policy might have to represent all the details of each person's tastes, abilities, and wealth; all the details of each firm's capital and technology; and all the details of any predetermined law, institution, or policy affecting the ways in which people and firms interact. No economist seriously hopes to have all the information necessary to build a model of this detail, and even if one existed no economist could manipulate it in a meaningful way. At a more realistic level, economists try to represent only some of the most important details of the economy in a model that can be manipulated so as to replicate the most important aspects of how the real economy would behave under various policies. If the right compromise can be struck-few enough details to allow the economist to construct and manipulate the model but enough details to allow the model 
to replicate accurately the behavior of the real economy under hypothetical circumstances--then the task of measuring the effects of policies is straightforward. The economist compares policies by representing them, one at a time, in the model and manipulating, or solving, each version of the model to predict, with reasonable accuracy, their respective effects.

No economist has yet constructed a model of the entire economy with enough detail to accurately evaluate all possible policies, and none is likely to. Furthermore, none of the hundreds of models that have been constructed specifically for analyzing the grain or livestock sectors of the U.S. economy have the detail necessary to evaluate all possible grain policies, and it can be argued that none of them are capable of accurately evaluating any policies, not even the policies they were designed to analyze [Lucas (1976), Sims (1980)]. This is because in order to construct and solve these agricultural models, the economists who designed them had to omit details whose absence probably causes significant errors in the models' predictions of the effects of agricultural policies. A reading of the literature on interactions between the grain and livestock sectors, for example, reveals several controversies and problems that hinge on which details can be safely omitted.

Omitted details of the technology for producing and processing livestock probably cause significant errors in many models of the livestock sector. For example, several models have been used to estimate the effect of beef import quotas on the U.S. livestock sector [Freebairn and Rausser (1975), Houck (1974), Anderson and Wilkinson (1983), Folwell and Shapouri (1980), Arzac and Wilkinson (1979a)]. Recently Ryan (1980) has convinced at least some economists [Martin and Heady (1984)] that these estimates may all be too high because they fail to take account of an important 
aspect of beef processing-the conversion of almost 25 percent of fed steer and heifer carcasses into hamburger, which had usually been modeled as coming from nonfed beef animals only. Many other aspects of the processing and marketing of livestock products are omitted from most livestock models. Gardner (1975), for example, argues that the simple mark-up formulas that represent marketing margins in many models are deficient. Most models also explicitly or implicitly represent livestock firms as homogeneous, thereby omitting the differences in technology and capital among livestock-producing firms.

Although consumers are not the focus of this paper, their preferences among the various livestock products can strongly influence the effects of grain programs on the livestock sector. For example, a sustained increase in the price of corn will probably eventually cause total livestock production to be cut. However, how much each livestock product will be cut depends on, among other things, how willing consumers are to substitute between meats and nonmeats and among the various types of meats. Anderson and Wilkinson (1983) have shown that including a more theoretically sound representation of consumers' preferences in a livestock model can significantly alter the estimated impacts of certain policies.

I have already discussed how difficult it is to even precisely define the grain programs, so it is no wonder that few models treat the grain programs as rules instead of sequences of actions. Even when treating policy as a sequence of actions, however, many models still omit potentially important aspects of the policy actions. The acreage reduction programs, such as set aside or diversion payments, of fer producers complicated incentives that are most accurately represented by probability distributions, not by single numbers such as the loan rate, the diversion 
payment, or the so-called effective support price. However, since it is very difficult to construct and manipulate models that represent the acreage reduction programs in terms of probability distributions, some agricultural economists have tried to find the best small set of numbers to represent the incentives they offer [see Bancroft (1981) for a recent attempt and a summary of previous efforts ]. No fully satisfactory approach has been developed so far, and similar problems arise in representing other complicated program incentives, such as those offered by the FORP, the basic CCC loan program, and the DPP.

The difficulty economists face in even precisely defining policies is related to the more general problem of representing how producers and consumers gather and process the information they need to make decisions. Work over the last twenty-five years has emphasized the importance of accurately representing these aspects of behavior [see Lucas and Sargent (1981), Sheffrin (1983)]. One of the earliest studies of this subject [Muth (1961)] showed that our interpretation of whether the hog cycle is caused by efficient or inefficient use of resources by hog producers depends on how we assume producers are forecasting hog and corn prices. Later work emphasized that assumptions about the formation of expectations determine how the behavior of producers under previous programs can be used to forecast their behavior under alternative programs [Lucas (1976)]. More recently economists have stressed the related point that realistic assumptions about how people form expectations would completely undermine the statistical procedures traditionally used to construct policy models [Sims (1980)].

Almost all currently available agricultural policy models use the traditional statistical procedures and assume that firms will forecast prices 
by some fixed procedure, even if a new policy is introduced that changes both the way prices actually evolve and the way that an efficient firm would forecast them. Because they are based on assumptions of such rigid and inefficient behavior, the policy simulations derived from these models may be seriously misleading. Gardner (1979) and others, for example, have pointed out that studies that assume that the response of private inventory holders to market prices will not change when the government institutes a price stabilization or buffer stock policy overestimate the effectiveness of the program. In addition, Bessler (1984) and Shonkwiler and Spreen (1982) have questioned the accuracy of the traditional statistical procedures used to estimate the policy models.

Despite evidence of the importance of information and expectations, it has been difficult to incorporate theoretically sound treatments of information gathering, information transmission, and expectations formation in agricultural policy models. Some efforts in this direction have been made [see Sheffrin (1983), Eckstein (1984), and Todd (1983)], but so far none of them have resulted in a practical policy model of the grain and livestock sectors. A new and controversial approach that uses nontraditional statistical techniques in an attempt to avoid having to model expectations formation [Sims (1982)] has not yet been applied to agricultural policy questions, although Bessler (1984) has taken some steps in this direction.

In discussing how omitted details limit the ability of agricultural policy models to accurately measure the effects of agricultural programs, I do not mean to say that models are useless. We have to make decisions, and manipulating a model of some kind is the only possible way to investigate our alternatives. Nor do I mean that agricultural economists 
have been remiss in not building accurate policy models, for we are only gradually learning how to improve the models' capacity for policy analysis. My point is that policymakers and other clients of model-building economists should regard all the available empirical evidence on the effects of the grain policies on the livestock sector, which I try to summarize below, with a skepticism fully justified by economic theory.

\section{ECONOMISTS' VIEWS ON HOW GRAIN PROGRAMS AFFECT THE LIVESTOCK SECTOR}

The details of the operation of U.S. grain programs are complicated and almost constantly changing, but their stated purposes--mainly to raise and stabilize farm income--have been simpler and more constant. In the 1950s, grain policy emphasized the enhancement of farm income through government-supported grain prices, but the high level at which prices were supported and the huge government grain inventories that resulted had the side effect of stabilizing grain prices as well. In the 1960s, farm income support was also pursued through direct cash payments to farmers, and as a result grain prices were allowed to fall part way toward free market levels and government grain inventories were reduced. When crop shortages and a surge in grain exports pushed grain prices to record levels in the early 1970s, policymakers began to take a more direct interest in stabilizing grain prices, and government subsidies for private grain storage were sharply increased. The subsidized inventories quickly grew large, although at least partly because inventories that would have been held anyway were shifted into the storage programs. Agricultural economists disagree about whether these recent programs have stabilized the grain market, but most of them hold that the programs have raised grain prices above free market levels in at least some years. 
There is little agreement, however, on how the direct effects of postwar grain policies--grain prices that were usually higher and sometimes (i.e., over at least some intervals) more stable than under free market conditions-have affected the livestock sector.

Policies have raised grain prices. For much of the last thirty years, most agricultural economists agree, grain policies have made grain prices higher than they otherwise would have been. Their effect on the level of grain prices probably peaked in the 1950s, diminished through the 1970 s, and rebounded in the 1980s.

In the 1950s the government directly supported grain prices through the Commodity Credit Corporation (CCC), which set its loan rates-the per bushel value on grain accepted as collateral for loans to farmers who were free to default if they wished--at high levels. Since most grain farmers were eligible for CCC loans, this policy prevented grain prices from falling very much below the loan rate. In addition, since political pressures pushed the loan rates to high levels, prices rarely rose above the loan rates either, and many farmers chose to default on their CCC loans. As a result, grain prices were determined mainly by the loan rate and the government acquired huge inventories of grain.

U.S. grain policies were changed in the 1960 s to support farm incomes with less direct effect on grain prices and inventories. Loan rates were gradually reduced, so that grain prices and government grain inventories could fall, but farmers received cash payments to make up for the lower price supports. The government reduced its inventories and supported farm prices by, in effect, renting farmland out of production. This was accomplished by requiring farmers who wished to be eligible for direct payments and $\mathrm{CCC}$ loans to idle some of their cropland. 
Almost all studies of grain policies in the 1950s and 1960s agree that the policies made grain prices higher than they would otherwise have been. Writing in 1967 , Tweeten reported a consensus of several studies that the grain programs had raised all farm prices (not just grain prices) by 10-20 percent, and some of the individual studies he cited estimated the effects on just grain prices in the range of 20-40 percent [Brandow (1960, 1961), Shepherd et al. (1960) ]. Cochrane and Ryan (1976, p. 360), reviewing this period and many of the same studies from the vantage point of the mid-1970s, reached the even stronger conelusions that the grain programs had raised grain prices above free market levels by 100 percent for wheat and 25 to 40 percent for corn.

Tweeten and Cochrane and Ryan cautioned that these were short-term results that did not take account of longer term reductions in land prices and farm labor and capital that might have occurred without the programs. Cochrane and Ryan also cite two studies that attempt to account for these longer-term effects. One, by Ray and Heady (1974), concluded that over the 1932-67 period government programs raised the prices of feed grains, wheat, and soybeans by 85,42 , and 27 percent, respectively. The other, by Nelson (1975), estimated that after about 15 years of lower free market prices so many resources would have been withdrawn from farming that the free market price would then begin to exceed prices experienced under the grain programs. This is perhaps the only study to conclude that the programs of the 1950 s and 1960 s might, at least eventually, have led to a sustained reduction in average grain prices.

Booming exports and poor erops changed the U.S. grain policy environment in the 1970s. In 1972-73, grain prices rose to record levels far above prevailing CCC loan rates, and subsequently grain prices began to fluctuate from year to year far more than in the 1950s and 1960 s. 
The initial boom in prices temporarily eased pressures for farm income support, and the trend of the 1960s to lower CCC loan rates continued. Direct income support payments were institutionalized in the target price system of the Agriculture and Consumer Protection Act of 1973. Under this system, producers who agree to leave some cropland idle receive cash payments, known as deficiency payments, to make up the difference between market prices (or the CCC loan rate, whichever is higher) and the target price for the grain they produce. Target prices are determined in part by estimates of the average nonland cost of producing each grain. Eligible producers are thus guaranteed at least the target price (less the per bushel equivalent of the earnings forgone on the idled land) while grain users buy at the generally lower market prices. In isolation, target prices with deficiency payments would subsidize grain production while dumping grain on world and domestic markets at less than a free domestic market price [Gardner (1981a, p. 39)], but their effect when used in combination with the other components of U.S. grain programs is less clear.

After the waning of the initial commodity price boom, policymakers expressed increased concern over the volatility of grain prices. This led to many studies of government-owned or -subsidized grain inventory management schemes and culminated in the establishment in 1977 of the Farmer Owned Reserve Program (FORP) for grains. When grain prices are low-below so-called release levels set by the Department of Agriculture according to guidelines established by Congress-this program subsidizes grain storage by farmers who have complied with the acreage reduction requirements of the target price program and who agree to leave the subsidized grain in storage until grain prices reach the release levels. 
When grain prices are high-above the release levels--the subsidies stop and participating farmers are free to sell the grain previously committed to storage.

For the boom and immediate postboom period of 1972-76 I have found few studies of how grain policy affected the average level of grain prices. One study [Congressional Budget Office (1976)] estimates that even in 1972 and 1973 , when grain prices were far above CCC loan rates, government supply control incentives extended to win farmers' votes in the 1972 elections accounted for over 20 percent of the increase in grain prices in those years. Gardner (1981a, p. 30) suggests that the Disaster Payment Program (DPP) begun in 1973, which provided free insurance against crop failure, may have encouraged farmers in drought-prone areas to switch from sorghum to corn, a higher yielding but more drought-sensitive crop. This could have reduced the price of corn relative to the price of sorghum over this period and until the early 1980s, when the DPP was phased out.

Concerning the period between 1977, when the FORP began, and 1980 , when exports to the Soviet Union were embargoed, agricultural economists do not agree on how grain programs affected the average price of grain. Some believe that the FORP itself was managed so as to stabilize but not raise grain prices over this period, but others hold that from its beginning it was used to raise grain prices. In addition, some studies indicate that the more traditional loan, target price, and supply control provisions of the grain programs probably acted to raise average grain prices in this period.

Morton, Devadoss, and Heady (1984) defend the proposition that the grain market stabilization goal of the FORP was attained without raising grain prices in the early years of this program. They construct an 
explicit model of the grain-livestock sector which suggests that a properly managed FORP could stabilize without raising grain prices and contend that the program was initially managed in this way. Gardner (1981b) finds little evidence that the FORP stabilized grain prices in the late 1970 s but agrees with Morton, Devadoss, and Heady that the program had little effect on average grain prices in that period. Just $(1981$, p. i) concludes that the FORP actually lowered average grain prices in the late 1970 s by sending "false price signals to the livestock industry," triggering a liquidation of herds and flocks.

Other studies conclude that the FORP raised grain prices above what they would have been had government grain inventory programs been limited to the traditional CCC loan program (which most agricultural economists believe raised grain prices). Arzac and Wilkinson's results (1979a, p. 306) indicate that higher government grain inventories, including those subsidized under FORP, boosted corn prices by close to 10 percent in 1978-79. Meyers and Ryan (1981, Table 2) estimate that the accumulation of FORP-subsidized grain inventories raised corn and wheat prices in individual years between 1977 and 1980 by from 3 to 7 and 10 to 25 percent, respectively, above what they would have been under previous inventory policies. They say these price-enhancing effects were partially offset in 1981, when they estimate that the release of FORP stocks reduced corn prices by 9 percent. On average their results weakly support Morton, Devadoss, and Heady concerning FORP's effects on corn prices but not on wheat prices, which they say the FORP raised an average of 7-11 percent over 1977-81. Salathe, Price, and Banker (1984, Table 2) reach less ambiguous conclusions. Using a fairly detailed model of the grain and livestock sectors they estimate that compared to a continuation of the previous 
government inventory programs the FORP raised grain prices in all years between 1977 and 1982, with an average effect over that whole period of 9 percent for wheat, 3 percent for corn, 2 percent for sorghum and oats, 6 percent for barley, and 1 percent for soybeans. Even in 1980-81, when FORP inventories were released after a drought pushed grain prices up, Salathe, Price, and Banker (p. 6) hold that prices would have been lower under previous policies.

Analysts generally agree that the FORP has been used to raise grain prices since 1981. The Salathe, Price, and Banker study extends through 1982, and according to Morton, Devadoss, and Heady (1984, p. 91), "In 1981 and 1982, the farmer-owned grain reserve, originally intended for price stabilization, was used to enhance farm prices and incomes."

The traditional loan, target price, and supply control programs apparently have also helped raise average grain prices above free market levels since 1977. In an early analysis of the Food and Agriculture Act of 1977, Gardner (1978a, pp. 101, 104) noted some offsetting effects--higher loan rates under the Act tended to raise average grain prices but its switch from an allotment system for determining the number of bushels for which the target price is guaranteed to a system based on actual acres planted encouraged grain production and thus reduced policies ${ }^{\dagger}$ upward pressure on grain prices. Focusing on the traditional components of the grain programs, he later estimated (1981a, pp. 68, 73) that the grain programs raised 1978-79 prices above free market levels by 15-20 percent for wheat and 6 percent for corn, sorghum, barley, and oats (taken as a group). Teigen, Bell, and Roop (1980, Table 2) find that supply control incentives like those used in 1979 (10 percent acreage set aside and diversion payment) would over time push corn and soybean prices above free market levels by 10 and 
20 percent, respectively; and Salathe, Price, and Gadson (1983, p. 143) estimate that 1982's Acreage Reduction Program alone raised corn prices by about 5 percent. Finally, Johnson and Clayton (1982, Table 1) claim that the combined effect of all grain programs in 1982 was to raise wheat prices by 20 percent; corn, sorghum, barley, and oats prices by $11-17$ percent, and soybean prices by 10 percent.

There are many problems with the estimates summarized above. As Tweeten (1967) and Cochrane and Ryan (1976, p. 360) observed concerning earlier studies, the studies of the more recent period are also generally short-run analyses, comparing the effects of the programs in a single year or at most a few years to what would happen if the programs were suddenly terminated or modified in some way. These effects, the recent studies generally find, are significant but less than the earlier studies found for the earlier period. Wheat prices are boosted by about 1025 percent; corn, sorghum, barley, and oats prices by about 5-15 percent; and soybean prices by $10-20$ percent. The recent studies still generally represent the grain programs as sequences of disconnected government actions rather than as decisions reflecting an underlying process or mode of behavior [Morton, Devadoss, and Heady (1984) is an exception], and they do not capture the equilibrium adjustments in land prices, farm capital and labor, and farmers' price expectations that would eventually occur if the grain programs were terminated. We may never be able to accurately capture those effects in quantitative detail [Gardner (1981a), p. 65].

Policies have not achieved pure grain price or quantity stabilization. Some agricultural economists have long maintained that policies that just stabilized grain prices, without raising or lowering them on average, would benefit grain producers, grain users, and society at large. 
However, the only grain programs that most agricultural economists agree helped stabilize the grain market were those of the I950s and, to a lesser extent, the $1960 \mathrm{~s}$, and these are also the programs which are thought to have raised average wheat and corn prices by as much as 100 and $25-40$ percent, respectively. Subsequently the grain programs seem to have stabilized grain prices intermittently at best, and some analysts feel their overall contribution has been to make grain prices both less stable and less predictable.

Opinion is almost unanimous both that the grain programs of the 1950s and 1960 s helped stabilize grain prices and supplies and that they did so somewhat inadvertently, as a by-product of supporting grain prices at high levels [Cochrane and Ryan (1976, p. 381); Johnson et al. (1976); Morton, Devadoss, and Heady (1984, p. 3)]. Simmons and Rizek (1966) and Gardner (1981a, p. 104) qualify slightly but do not disagree. The former authors note that the programs of the $1960 \mathrm{~s}$, with loan rates sometimes below market prices, stablilized somewhat less than those of the 1950 s. The latter suggests that the grain markets were subjected to smaller economic shocks in the 1950 s and 1960 s than after 1970 and that therefore the stabilization features of the grain programs in this earlier period were not tested severely. Gardner also argues (1981a, p. 110) that even in this period the level at which prices were supported was responsive to political and budgetary pressures over time, and that this preserved an element of risk in long-term investments in agricultural land and capital.

When government grain inventories were depleted in the commodity boom of $1972-73$, the government's role in stabilizing the grain markets was also eliminated and possibly reversed. Shortly after these events (and similar events involving other policies and markets), Robinson 
(1975, p. 772) observed, "Government intervention ... can become a destabilizing factor in pricing farm products." Gardner (1981a, p. 104) complains that this was exactly the case in the grain price boom of the mid1970s, as government grain inventories "were of little use when stabilization was really needed. ... Indeed, in this episode it seems likely that government was an important agent of instability," partly because of mismanaged supply controls and inventory reductions. The Congressional Budget Office (1976, pp. 35,36 ) agrees that politically motivated delays in cutting off the supply control incentives of the grain programs after exports began to surge destabilized the grain market.

The Agriculture and Consumer Protection Act of 1973 significantly revised the ways in which grain prices and grain farmers' incomes would be supported, but it contained no significant provisions for grain market stabilization. In fact, by continuing the trend toward reduced loan rates and government inventories, it left grain prices more free then ever to move upward in response to sudden increases in demand or shortfalls in production [Breimyer and Rhodes (1975, p. 945); Hathaway (1981, p. 786); Roberts and Heady $(1980$, p. 7$)]$.

During the four-year term of the 1973 Act agricultural economists debated the government's role in stabilizing grain markets and studied many grain stabilization proposals. Those who believed that the government can and should act to stabilize grain markets apparently were most persuasive, for the FORP of the Food and Agriculture Act of 1977 deepened the government's involvement in grain storage.

After seven years of experience with the FORP these debates are still going on. Some agricultural economists hold that the FORP could stabilize grain markets, possibly without also raising average grain prices, 
and they sometimes point to the $1977-80$ period as evidence. Others contend that in practice government inventory schemes like FORP destabilize grain markets, and they sometimes point to the period since 1980 as evidence. Both sides agree that since 1980 the grain programs have been used more to raise than to stabilize grain prices, but the side that believes the government can stabilize the grain market sees this as an isolated episode of mismanagement while the other side sees it as a manifestation of the administrative and political pitfalls inherent in such a program.

Many agricultural economists in the mid-1970s realized that in 1977, when Congress was again to review the country's basic agricultural programs, some government program for grain market stabilization was likely to be passed, and many of these economists published theoretical or empirical studies of hypothetical government grain inventory policies. Many of the empirical studies estimated that the government could reduce the coefficient of variation (a measure, in percentage terms, of the typical size of a variable's changes or deviations from average) of grain prices or quantities [see Walker, Sharples, and Holland (1976) or Ericksen, Ray, and Richardson (1976)]. Critics of government storage programs stressed theoretical arguments that private inventory holders could provide all (or at least most) of the benefits of grain stabilization function if only the government would make a commitment to keep out of (or consistently limit its involvement in) the grain storage business [Stein and Smith (1977); Gardner (1979) ]. They also objected that the empirical models of government grain storage omitted or oversimplified too many important aspects of market behavior, such as the depressing effect of government inventory accumulation and release rules on private inventories [Gardner (1979), p. $122]$. 
Opinions remain divided even with several years of experience under the FORP and the other grain program changes of the Food and Agriculture Acts of 1977 and 1981. For example, the design of the FORP has drawn mixed reviews. Some economists argue that it has and will mainly displace private stocks or that the spread between its loan rates and release prices is so wide that the FORP cannot stabilize grain prices as well as the previous $\mathrm{CCC}$ policy of releasing accumulated government inventories when grain prices reached 115 percent of the CCC loan rate [Salathe, Price, and Banker (1984, p. 6); Gardner (1978a, p. 104); Gardner (1981b)]. This view, say others, ignores the FORP's added incentives for storing grain even at prices somewhat above the loan rate, which make grain demand more elastic and reduce grain market fluctuations [Meyers and Ryan (1981, p. 319)].

Measurements of the actual performance of the FORP also differ. On theoretical grounds, this is not surprising. Stabilization can be accurately measured only with a long history of experience, one that includes numerous examples of the kinds of supply and demand shocks that the stabilization policy is supposed to smooth out. Nonetheless, our briefer history is all that is available, and economists are bound to try to read its message, however obscure it may be. Salathe, Price, and Banker tried, and they found no statistically significant evidence that the FORP affected the volatility of grain prices in the period 1977-82. Earlier Gardner (1981b) had reached the same conclusion for the 1977-79 period. Morton, Devadoss, and Heady (1984, pp. 83-88) reached the opposite conclusion: the FORP, supplemented by supply control programs, not only can stabilize grain prices without raising them on average but also actually tended to do so in 1977-80. They estimate that wheat and corn price fluctuations were re- 
duced by about 50 and 25 percent, respectively, by the grain programs of this period. Repeating this success in the future, they say, would require government inventories about 40 percent larger than in 1977-80 and supply control measures about every other year. Offutt (1982, p. 88) and Arzac and Wilkinson (1979a, p. 305) also find that FORP inventories would have to be larger than in $1977-80$ if the program is to smooth out the effects of export demand fluctuations of the size the United States experienced in the I 970 s.

To some, the design of the stabilization programs of the 1977 Act has never been as worrisome as their administration. In an early comment on the Act, Gardner (1978a, pp. 102-104) noted that it increased the Secretary of Agriculture's authority to modify key program provisions, such as loan rates, and that past experience suggested that this authority would not be used to stabilize markets. The actual administration of the Act did little to change his view; he later cites the 1978 supply control incentives as an example of a possibly destabilizing administrative decision (1981a, p. 113).

Gardner's fears of destabilizing management of the grain programs were fully borne out in the $1980 \mathrm{~s}$, most analysts agree. As Gardner (1981a, p. 37) himself observes, "Almost every policy parameter in the reserve program was changed in early 1980 in order to cope with the embargo of shipments to the Soviet Union. As a stabilization program, it is disquietingly variable." Grain policy shifted "away from [the] stabilization of the Iate 1970s and toward income enhancement," according to Morton, Devadoss, and Heady (1984, p.7), and this led first to excessive incentives to grow and store grain in 1981 and 1982 and then to "an unprecedented acreage reduction program" in 1983. The net effect, which they blame on 
inconsistent management of the programs (pp. 92, 93), is that (p. 7) "agricultural markets have been subjected to a whipsaw price effect. . . Moreover, these recent program changes have created uncertainty about policy direction, perhaps adding to instability." Neither Gardner (1981a, p. 105) nor Hathaway ( 1981 , p. 786) expects we will soon learn to manage stabilization programs effectively.

The goal of stabilizing grain markets over a long period of time without simultaneously raising the average price of grain continues to elude U.S. policymakers. Stabilization was achieved for almost 20 years, from the Korean War to the Soviet wheat deal of 1972 , but only as the inadvertent by-product of an expensive price support system. Subsequent attempts to stabilize without raising grain prices have had limited success at best, perhaps only in 1977-80 and possibly not even then. In the eyes of some observers, however, these programs still are promising, for their failures were caused not by faulty design but rather by faulty and potentially correctable management. Others believe that experience has shown repeatedly that the destabilizing conversion of stabilization policies into price support policies, as was most recently observed in 1980-83, is more typical of what these attempts will lead to.

Economists agree in general, but not in detail, on how higher feed prices have affected levels of production, prices, and incomes in the livestock sector. In general, most studies of the grain programs show that the programs have tended to raise grain prices anywhere from 5 to 100 percent, depending on the particular crop and time period. Higher grain prices affect the livestock sector in several ways. The most direct way, and the one that has received the most study, is by raising the cost of animal feed. Economists generally agree that higher feed prices curtail 
production and boost prices and sales volume of most kinds of livestock, but the evidence and arguments on their effects on individual livestock subsectors are inconclusive.

Over the last thirty years hundreds of econometric models of the livestock sector have been used to estimate the effects of changes in feed prices on the livestock sector. As discussed above, these models omit many important aspects of the actual livestock sector and their estimates are thus highly subject to error. The divergent implications of these many models no doubt partly reflect these errors and differences in exactly which details of the sector the models omit. Nonetheless, these models are the main source of information on how higher costs of feed for animals, such as have been brought about by the grain programs, affect the livestock sector. (Theoretical work on this topic has led to only a few results and little detailed information.) Some of these econometric models have been used to directly investigate the effects of a complicated set of grain programs on the livestock sector, but others merely contain information about the effects of the higher feed prices that the grain programs produce.

The models that estimate only the effects of higher feed prices generally show that the production of total livestock and most individual forms of livestock declines in response to higher feed costs, as simple economic theory might suggest. As shown in Table 1 , common estimates are that in response to a sustained 10 percent increase in some measure of feed prices (an increase in the range of those the grain programs are thought to have produced), chicken, turkey, and egg production would decline by $0.3-1.2$ percent; total beef production by $1-3$ percent; and hog production and beef cow and sow numbers by 0-6 percent. Despite the range of these typical estimates, some studies indicate even stronger effects. 
The effects on the beef sector are also obscured unless more detail is provided. For example, Ospina and Shumway's (1981, p. 702) estimate that total beef production declines 1.1 percent in response to a sustained 10 percent increase in corn prices is near the lower end of the range of estimates of this effect. It conceals, however, a 4.2 percent drop in production of choice beef that is partly offset by a 4.9 percent increase in production of lower grade utility beef. This illustrates that adjustments in the livestock sector to higher feed prices need not be uniform across nor even within the beef, pork, lamb, and poultry subsectors.

With livestock quantities generally estimated to fall in response to higher feed prices, livestock prices are generally estimated to rise, but the range of estimates is even wider than for quantities. Table 2 shows that a sustained 10 -percent increase in corn prices has been found to lead to farm-level price increases of almost -1 to at least 5 percent for all beef; 1-12 percent for steers or choice beef; 2-10 percent for cows; -8 to 11 percent for feeder calves; 2-9 percent for hogs; 1-7 percent for broilers; 14 for eggs; and 1-9 percent for turkeys. Note that the effects on the beef sector as a whole again mask larger but partly offsetting effects on steers, cows, and calves; and that the range of estimated effects is especially large for the price of beef calves.

Most of these models estimate that the net effect of a sustained increase in feed prices is to boost gross farm income from livestock, because farm livestock prices rise by more than farm livestock production falls. (Apparently most of these models include inelastic farm-level demands for livestock products, a conventional practice supported by empirical evidence.) Some economists seem to regard gross income from livestock sales as a measure of livestock producers' well-being and self-interest 
[Prindle (1979, p. 297)], but a more relevant measure in this context might be income (from livestock sales) net of feed costs. Feed costs are roughly three-fourths of the variable costs of fattening a steer or producing a hog, chicken, or turkey. If gross income from these activities rises by much less than 7.5 percent in response to a 10 percent increase in feed prices, it is likely that net income has fallen or that the prices of other inputs, such as feeder calves or rangeland in the case of beef, have been bid down. Table 3 shows that most, but not all, studies estimate that a sustained 10 percent increase in corn prices will increase gross income from livestock sales by less than 7.5 percent.

The elasticities in Tables 1-3 are taken mainly from studies that did not specifically address the effects of higher feed prices on the livestock sector, so it is not surprising that from these studies we can draw only fairly vague conclusions. Several studies have more directly estimated these effects and drawn more detailed conclusions about them. Some of their findings are similar--that higher feed prices reduce production of most kinds of livestock and raise prices as well as gross income from sales of most kinds of livestock. However, some of these studies go farther, estimating how livestock producers' net income or welfare is affected and which livestock sectors are affected the most by higher feed prices. As always, their estimates are highly subject to error, and the conclusions of one study are often contradicted by another.

Some of the studies conducted in the 1950s and 1960s mainly confirm the general conclusions discussed. Nelson's work, cited by Cochrane and Ryan (1976, p. 363), shows a favorable situation for the livestock sector in 1953-67, with livestock production reduced only slightly and percentage increases in average livestock prices and gross receipts 
Table 1

Long-Run Response of Livestock Quantities to Grain Prices

Percentage

Response to 8

Sustained 10

Percent Rise

Exact Cause

in Grain Prices

and Length

of Response

(See Key)

Source

BEEF PRODUCTION

Total

$-2.9899$

$-2.6200$

$-2.0500$

$-1.5300$

$-1.4680$

$-1.2780$

$-1.1000$

Fed or Choice

$-13.5000$

$-4.2000$

$-3.6000$

$-3.1581$

$-0.7828$

Other Slaughter

$$
\begin{aligned}
& \text { Nonfed } \\
& -5.4871 \\
& -2.9694 \\
& 0.5300 \\
& 60.0000
\end{aligned}
$$

(C, 200)

(C, 200)

(C, 24)

(C, 200)

(C, 200)

$(\mathrm{C}, 24)$

(C, 200)

(C, 200)

(C, 200)

(G, 24$)$

(CB, 84)

(C, 200)

(C, 200)

Good

$$
0.5000
$$

$(C, 200)$

$(\mathrm{C}, 200)$

$$
4.9000
$$

$(C, 200)$

$$
-7.8321
$$

Calves and Feeder Cattle

$$
-2.7000
$$

$-13.8920$

$$
(\mathrm{C}, 24)
$$$$
\text { (C, 200) }
$$

\section{BEEF INVENTORY}

Cows

$\begin{array}{ll}-4.9031 & (C, 200) \\ -4.0670 & (C, 200) \\ -2.8200 & (C, 200) \\ -0.3925 & (C, 200)\end{array}$

Heifers Kept

$-4.7670$

$(C, 200)$

Salathe and Price

Calves
$-3.7750$
(C, 200)
Salathe and Price

Yearlings
$-0.3302$
$(C, 200)$
Folwell and Shapouri (1980)

Salathe and Price

Folwell and Shapouri (1980)

Bain (1976)

Spathis (1983)

Ospina and Shumway (1981)

Ospina and Shumway (1981)

Salathe and Price

Bain (1976)

Salathe and Price

Salathe and Price

Martin and Haack (1977)

Reutlinger (1966)

Folwell and Shapouri (1980) 
Table 1

Long-Run Response of Livestock Quantities to Grain Prices, Continued

Percentage

Response to a Exact Cause

Sustained 10 and Length

Percent Rise of Response

in Grain Prices (See Key)

Source

PORK PRODUCTION

Total

$\begin{array}{ll}-25.5000 & (\mathrm{C}, 200) \\ -4.1815 & (\mathrm{C}, 200) \\ -1.4110 & (\mathrm{G}, 24) \\ -1.2500 & (\mathrm{C}, 200) \\ -1.7300 & (\mathrm{C}, 24) \\ -1.1260 & (\mathrm{C}, 84) \\ -0.3800 & (\mathrm{C}, 60) \\ -0.1900 & (\mathrm{M}, 200) \\ -0.8000 & (\mathrm{C}, 200)\end{array}$

Spathis (1983)

Folwell and Shapouri (1980)

Salathe, Price, and Banker (1984)

Heien (1975)

Bain (1976)

Roberts and Heady (1980)

Egbert and Reutlinger (1965)

Heien (1975)

Martin and Zwart (1975)

PORK INVENTORY

Sows

$-6.1111 \quad(C, 200) \quad$ Folwell and Shapouri $(1980)$

Pigs

$-6.1223 \quad(C, 200) \quad$ Folwell and Shapouri (1980)

LAMB PRODUCTION

$-8.2400 \quad(\mathrm{CB}, 84) \quad$ Roberts and Heady (1980)

\section{POULTRY PRODUCTION}

Chicken or Broilers

$\begin{array}{ll}-18.0000 & (\mathrm{C}, 200) \\ -0.8200 & (\mathrm{C}, 60) \\ -0.7750 & (\mathrm{G}, 24) \\ -0.6720 & (\mathrm{C}, 200) \\ -0.5490 & (\mathrm{M}, 200) \\ -0.4680 & (\mathrm{CB}, 84) \\ -0.2000 & (\mathrm{C}, 200) \\ -0.3000 & (\mathrm{M}, 200) \\ 0.9235 & (\mathrm{C}, 200)\end{array}$

Turkey

$-1.2370$

$-1.0110$

$-0.5560$

$-0.4000$

$-0.2000$

$-0.2000$

$-0.0320$

(C, 200)

$(\mathrm{M}, 200)$

(G, 24)

(C, 60)

(C, 200)

$(\mathrm{M}, 200)$

$(\mathrm{CB}, 84)$

Spathis (1983)

Egbert and Reutlinger (1965)

Salathe, Price, and Banker (1984)

Chavas (1978)

Chavas (1978)

Roberts and Heady (1980)

Heien (1976)

Heien (1976)

Folwell and Shapouri (1980)

Eggs

$\begin{array}{rll}-14.0000 & (\mathrm{C}, 200) & \text { Spathis (1983) } \\ -0.9690 & (\mathrm{C}, 200) & \text { Chavas (1978) } \\ -0.6950 & (\mathrm{G}, 24) & \text { Salathe, Price, and Banker (1984) } \\ -0.4800 & (\mathrm{C}, 60) & \text { Egbert and Reutlinger (1965) } \\ -0.3430 & (\mathrm{M}, 200) & \text { Chavas (1978) }\end{array}$

Key: See notes after Table 3. 
Table 2

Long-Run Response of Livestock Prices to Grain Prices

Percentage

Response to a Exact Cause

Sustained 10 and Length

Percent Rise of Response

in Grain Prices

(See Key)

Source

BEEF

Total

$\begin{array}{rll}-0.9000 & (\mathrm{C}, 200) & \text { Ospina and Shumway (1981) } \\ 4.5300 & (\mathrm{C}, 60) & \text { Egbert and Reutlinger }(1965) \\ 5.6900 & (\mathrm{CB}, 84) & \text { Roberts and Heady }(1980)\end{array}$

Steers or Choice

$0.7000 \quad(\mathrm{C}, 200) \quad$ Ospina and Shumway (1981)

$0.8610 \quad(\mathrm{G}, 24)$

$2.9300 \quad(\mathrm{C}, 24)$

$3.5000 \quad(\mathrm{C}, 200)$

$6.9873 \quad(\mathrm{C}, 200)$

$10.0000 \quad(\mathrm{C}, 200)$

$11.5386 \quad(\mathrm{C}, 200)$

Salathe, Price, and Banker (1984)

Bain (1976)

Arzac and Wilkinson (1979a)

Folwell and Shapouri (1980)

Reut linger (1966)

Salathe and Price

Other

Good or Total Nonfed

$\begin{array}{lll}-0.5000 & (\mathrm{C}, 200) & \text { Ospina and Shumway (1981) } \\ +2.2700 & (\mathrm{C}, 24) & \text { Bain (1976) }\end{array}$

Utility

$-5.1000 \quad(\mathrm{C}, 200) \quad$ Ospina and Shumway $(1981)$

Cows

$1.8600 \quad(\mathrm{C}, 200) \quad$ Arzac and Wilkinson (1979a)

$9.7784 \quad(\mathrm{C}, 200) \quad$ Folwell and Shapouri $(1980)$

Calves and Feeder Cattle

$-8.3000 \quad(C, 200)$

$-3.6700 \quad(C, 200)$

$1.0000 \quad(C, 200)$

$1.6200 \quad(\mathrm{C}, 96)$

$2.0000 \quad(\mathrm{C}, 24)$

$10.5153 \quad(\mathrm{C}, 200)$

Martin and Haack (1977)

Marsh (1983)

Arzac and Wilkinson (1979a)

Ray and Trapp (1977)

Bain (1976)

Salathe and Price

PORK

$\begin{array}{lll}0.3000 & (\mathrm{M}, 200) & \text { Heien }(1975) \\ 2.0100 & (\mathrm{C}, 200) & \text { Heien (1975) } \\ 2.0400 & (\mathrm{C}, 96) & \text { Ray and Trapp (1977) } \\ 3.3300 & (\mathrm{C}, 24) & \text { Bain (1976) } \\ 3.5769 & (\mathrm{C}, 200) & \text { Salathe and Price } \\ 4.6000 & (\mathrm{C}, 200) & \text { Arzac and Wilkinson }(1979 a) \\ 5.3970 & (\mathrm{G}, 24) & \text { Salathe, Price, and Banker }(1984) \\ 5.5700 & (\mathrm{C}, 60) & \text { Egbert and Reutlinger }(1965) \\ 5.9270 & (\mathrm{CB}, 84) & \text { Roberts and Heady }(1980) \\ 8.9020 & (\mathrm{C}, 200) & \text { Folwell and Shapouri }(1980)\end{array}$

LAMB

$1.3610 \quad(\mathrm{CB}, 84) \quad$ Roberts and Heady (1980) 
Table 2

Long-Run Response of Livestock Prices to Grain Prices

Continued

Percentage

Response to a Exact Cause

Sustained 10 and Length

Percent Rise of Response

in Grain Prices $\quad$ (See Key)

Source

\section{POULTRY}

Total
6.3162
(C, 200)
Salathe and Price

Chicken or Broilers

$\begin{array}{ll}0.9000 & (\mathrm{C}, 200) \\ 1.3000 & (\mathrm{M}, 200) \\ 1.3230 & (\mathrm{M}, 200) \\ 1.6180 & (\mathrm{C}, 200) \\ 3.4300 & (\mathrm{G}, 24) \\ 5.6000 & (\mathrm{C}, 200) \\ 5.9020 & (\mathrm{CB}, 84) \\ 6.6700 & (\mathrm{C}, 60) \\ 6.7148 & (\mathrm{C}, 200)\end{array}$

Heien (1976)

Heien (1976)

Chavas (1978)

Chavas (1978)

Salathe, Price, and Banker (1984)

Arzac and Wilkinson (1979a)

Roberts and Heady (1980)

Egbert and Reutlinger (1965)

Folwell and Shapouri (1980)

Turkey

0.6000

(C, 200)

(M, 200)

0.8000

(M, 200)

1.4200

(C, 200)

3.6400

(C, 60)

3.7280

$(\mathrm{G}, 24)$

8.7930

(CB, 84)

Heien (1976)

Heien (1976)

Chavas (1978)

Chavas (1978)

Egbert and Reutlinger (1965)

Salathe, Price, and Banker (1984)

Roberts and Heady (1980)

Eggs

$\begin{array}{ll}0.9720 & (\mathrm{M}, 200) \\ 2.1660 & (\mathrm{G}, 24) \\ 2.9380 & (\mathrm{C}, 200) \\ 4.1300 & (\mathrm{C}, 60)\end{array}$

Chavas (1978)

Salathe, Price, and Banker (1984)

Chavas (1978)

Egbert and Reutlinger (1965)

Key: See notes after Table 3. 
Table 3

Long-Run Response of Livestock Producers'

Gross Income to Grain Prices or Supplies

Percentage

Response to a

Sustained 10

Percent Rise in

Exact Cause

Prices or Fall in

and Length

of Response

Supplies of Grain (See Key)

Source

BEEF

Total

$-24.3000$

2.3900

3.5690

6.8466

Steer or Choice
$-3.8000$
$-1.7200$
5.6000
(C, 24)
(C, 200)

Other

Good or Total Nonfed

$-0.0250 \quad$ (C, 200)

2.9000

(C, 24)

Utility

$-2.7000$

(C, 200)

(C, 200)

9.0000

(C, 24)

Bain (1976)

Prindle (1979)

Egbert and Reutlinger (1965)

Roberts and Heady (1980)

Salathe and Price

Ospina and Shumway (1981)

Bain (1976)

Folwell and Shapouri (1980)

Ospina and Shumway (1981)

Bain (1976)

Ospina and Shumway (1981)

Folwell and Shapouri (1980)

Feeder Cattle

$-1.2000$
Heien (1975)

Heien (1975)

Folwell and Shapouri (1980)

Bain (1976)

Roberts and Heady (1980)

Egbert and Reutlinger (1965)

Prindle (1979)

$(\mathrm{Q}, 200)$

5.1690
21.9000

LAMB

$$
-8.6230
$$

(CB, 84)

Roberts and Heady (1980)

\section{POULTRY}

Chicken or Broilers

$\begin{array}{ll}0.6800 & (\mathrm{C}, 200) \\ 0.7010 & (\mathrm{M}, 200) \\ 0.8370 & (\mathrm{C}, 200) \\ 0.9600 & (\mathrm{M}, 200) \\ 4.8850 & (\mathrm{CB}, 84) \\ 5.7950 & (\mathrm{C}, 60) \\ 8.3000 & (\mathrm{C}, 200) \\ 14.8000 & (\mathrm{Q}, 200)\end{array}$

Heien (1976)

Chavas (1978)

Chavas (1978)

Heien (1976)

Roberts and Heady (1980)

Egbert and Reutlinger (1965)

Folwell and Shapouri (1980)

Prindle (1979) 
Table 3

\title{
Long-Run Response of Livestock Producers' Gross Income to Grain Prices or Supplies, Continued
}

Percentage

Response to $\mathrm{a}$

Sustained 10

Percent Rise in

Prices or Fall in

Supplies of Grain

\author{
Exact Cause \\ and Length \\ of Response \\ (See Key) \\ Source
}

POULTRY, continued

Turkey

$-10.8000$

0.0070

0.0330

0.3900

0.5800

3.2250

9.2290

$(\mathrm{Q}, 200)$
$(\mathrm{C}, 200)$
$(\mathrm{M}, 200)$
$(\mathrm{C}, 200)$
$(\mathrm{M}, 200)$
$(\mathrm{C}, 60)$
$(\mathrm{CB}, 84)$

Prindle (1979)

Chavas (1978)

Chavas (1978)

Heien (1976)

Heien (1976)

Egbert and Reutlinger (1965)

Roberts and Heady (1980)

Eggs

$0.5960 \quad(\mathrm{M}, 200) \quad$ Chavas (1978)

$1.6840 \quad(C, 200) \quad$ Chavas (1978)

$3.6300 \quad(\mathrm{C}, 60)$

14.4000

$(\mathrm{Q}, 200)$

Egbert and Reutlinger (1965)

Prindle (1979)

Key (Cause, number of quarter to take effect):

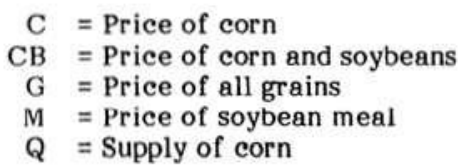

Note: The author of this paper calculated many of the responses in Tables 1,2 , and 3 from data in the sources noted above. Any errors in interpreting these data are solely the responsibility of the author of this paper. Responses that take more than 200 quarters are listed above as taking only 200 quarters. 
exceeding or roughly matching, respectively, the policy-induced increases in crop prices. Brandow's results (1961) were less favorable: livestock prices in 1955-57 matched barely over half the 20 percent increase in corn prices brought about by the grain programs.

Other early studies attempt to determine the effects of the grain programs on individual livestock subsectors. Shepherd et al. (1960), who estimate that the combined wheat and feedgrain programs of 1952-58 raised corn prices by over 35 percent, use fixed ratios to distribute the resulting overall reduction in feed use among the livestock subsectors. On this basis they project that the grain programs decreased production and raised prices and gross incomes in all the livestock subsectors. The strongest effects were on the pork, egg, and poultry subsectors, whose gross incomes were boosted by 15,13 , and 9 percent, respectively. They do not distinguish between fed and nonfed beef production, which may account for the moderate impacts on the beef sector which they estimate, but they estimate that the grain programs increased gross income from sales of young animals such as feeder calves. This effect is consistent with Robinson's conclusion (1965, p. 1234) that "producers who sell livestock products based on homegrown feed have gained relative to those who purchase feed and convert it into livestock products." However, by raising corn prices relative to soybean prices the grain programs may have shifted resources from the production of beef to the production of hogs and broilers, which are more dependent on soybean meal [Colyer and Irwin (1967, p. 61)].

More recent Department of Agriculture studies find that higher corn prices boost gross income more for pork and poultry producers than for beef producers. Two papers based on the Department's FAPSIM model support this conclusion. Salathe, Price, and Gadson (1983, p. 145) estimate 
that a five-year program of reduced corn acreage would raise corn prices by about 5 percent and slightly increase pork production, prices, and gross income because of the large cuts in beef production that it would cause. Salathe, Price, and Banker (1984, Table 2) find that the FORP raised 197782 feedgrain prices by an average of 3 percent and that this lowered production and raised prices of beef, hogs, broilers, eggs, and turkeys. Cowcalf producers bore much of the estimated burden, as gross income from all livestock and from cattle and calves fell while gross income from hogs and poultry products rose. Similar findings for a shorter time period come from a joint effort of Department of Agriculture econometricians and livestock market analysts, who infer that an acreage reduction program that raised feedgrain prices about 10 percent over a two-year period would raise gross income from steers, hogs, and especially broilers while cutting prices and sales revenue for feeder calves [Teigen, Bell, and Roop (1980, p. 48)]

Two other studies agree that higher feed prices raise gross incomes more for pork and chicken producers than for beef producers, but they sharply disagree over turkey producers' situation and adjustments within the beef sector. Prindle's (1979, p. 296-7) simulation of a five-year reduction in feedgrain supplies (which would raise feedgrain prices) shows that gross income would fall for turkey and especially beef producers and rise for egg, chicken, and especially pork producers. Roberts and Heady (1980) find that, after twenty years of approximately a 100 percent increase in grain and soybean prices, producers' gross incomes would be up about 90 percent for turkey, 50 percent for chicken, 40 percent for hogs, and 35 percent for beef. The disagreement over the turkey subsector may reflect differences in the two models' estimates of consumers' willingness to substitute turkey for other meats. In addition, Prindle's model has the 
conventional implication that higher feed prices would cause a shift within the beef sector from fed to nonfed beef production, whereas Roberts and Heady's model seems to imply that higher prices for fed beef would eventually reverse that conventional result.

Not all recent studies find the beef sector to be relatively disadvantaged by higher feed prices, however. Folwell and Shapouri's (1980) model implies that a sustained I0-percent rise in corn prices would cut mainly hog, not beef, production, and that as a result producers' gross income would rise about 9 percent for cows and broilers, 5-6 percent for steers, and only 1 percent for hogs. Ray and Trapp (1977, p. 39), citing work by Department of Agriculture econometricians, report that six years of 20-percent higher feed costs would cut production and raise prices more for hogs than for beef but raise gross income for both by about 5 or 6 percent.

The gross income estimates in all these studies are not themselves good measures of livestock producers' well-being, although they can be compared to the associated increases in feed prices to get a rough idea of the effects of higher feed prices on producers' returns over variable costs. A few studies, however, try to measure these net returns. Teigen, Bell, and Roop (1980) provide no product-by-product detail but report that total feed expenses of the livestock sector rise almost a third again as much as total livestock gross income. The same sort of result holds for both the beef and hog subsectors in Ray and Trapp's study (1977, p. 39). Hallam (1983) seems to make the most ambitious attempt to incorporate measures of livestock producers' well-being in a model of the feedgrain livestock sector, and his results are somewhat different. He finds that when government inventories are used to raise feed prices, "pork, poultry, 
and cow-calf producers lose.... Feedlot operators gain as higher feed prices cause a significant cutback in slaughter and a rise in prices of fat beef and a fall in feeder calf prices."

It is hard to wring firm conclusions out of all these studies of the effects of higher feed prices on the livestock sector. Many but not all of them are consistent with the notion that producers of feeder animals are most hurt by higher feed prices because livestock feeders, especially beef feedlot operators, maintain their margins by bidding feeder animal prices down when feed prices rise. Since cow-calf producers can, in turn, reduce their bids for pasture and forage supplies, even this conclusion might have to be modified to state that the owners of pasture and forage-producing land (who are sometimes but not always cow-calf operators) are most disadvantaged. Even less clear are the effects on the other livestock subsectors, especially the hog subsector, where many producers also produce large quantities of the grains whose prices are supported. Nearly 20 years of research has perhaps only given us more reasons to agree with Tweeten's warning $(1967$, p. 113) that "individual commodity effects . . . cannot be estimated with a practical degree of reliability."

Economists generally disagree about the effects of feed price volatility on volatility in the livestock sector. The supply-demand linkage between the grain and livestock sectors tends to transmit at least some of the volatility in either sector to the other. Shocks to feed prices are buffered to some extent by the offsetting fluctuations and cycles they trigger in the livestock sector [Breimyer (1954), Gustafson (1977)], as livestock serve to store or release grain in the form of meat [Roberts and Heady (1980), Gardner (1981a)]. Shocks to the livestocik sector are also transmitted to the grain sector, for livestock feed is still the largest market for important grains such as corn and sorghum. 
These linkages between the grain and livestock sectors would seem to imply that programs which stabilize the price of feed would also stabilize the livestock sector, and some economists have argued that this is one of the effects of the grain programs. One problem with this argument, as we have seen, is that there is spotty evidence at best that the grain programs have stabilized feed prices at all over the last ten to fifteen years, or that they have ever stabilized feed prices without simultaneously raising them. Another problem is that measurements of the extent to which stable feed prices stabilize livestock markets and livestock producers' incomes conflict, with several studies showing very small effects. (The further question of how much livestock producers benefit from a reduction in the variability of their incomes brought about by the grain programs is also relevant but is not examined here.)

Empirical studies, mostly of the period of relatively stable but high feed prices in the $1950 \mathrm{~s}$ and $1960 \mathrm{~s}$, disagree in important respects. Nelson [see Cochrane and Ryan (1976, pp. 362-3)] estimates that without the grain programs in place from 1953 to 1972 livestock prices would have cycled much more strongly than they did. Backhanded support for the linkage between feed and livestock price stability comes from the 1972-73 period, when grain policy apparently destabilized both [Congressional Budget Office (1976, p. 91)]. Simmons and Rizek (1966) also find evidence of this linkage, noting that as grain prices stabilized after 1945 so did beef prices and beef and hog production. They also note, however, that the fluctuations in hog prices did not seem to abate. Robinson (1975, p. 771) compared the corn, egg, and hog prices of the $1920 \mathrm{~s}$ to those of the $1960 \mathrm{~s}$. His findings-that the volatility of corn prices had fallen by over half but the volatility of egg and hog prices had hardly changed at all-led him to 
caution that livestock producers shouldn't expect too much from the grain programs because feed price stability is at best a necessary, and not a sufficient, condition for livestock price stability. One economist who had stressed the advantages of stable feed prices concluded [Breimyer (1959, p. 762) ] that "programs to date ... have not achieved as much stability in hogs and other livestock as has been envisioned."

Recent studies of the relationship between feed and livestock market volatility have used econometric models to simulate the effects on the livestock sector of stable feed prices, but they still disagree. Walker, Sharples, and Holland (1976) used a highly aggregative feedgrain-livestock model and estimated that a government wheat and corn inventory program would not affect the variability of livestock production but would reduce the variability of prices by about 50 percent for feed and 37 percent for livestock. Other studies find little relationship between feed and livestock volatility. Ericksen, Ray, and Richardson (1976) concluded that a program similar to the FORP would reduce price swings by 15-20 percent for corn and soybeans but only -1 (an increase) to 4 percent for cattle and calves. Morton, Devadoss, and Heady (1984) simulate a twenty-year program of using the FORP to stabilize but not raise feed prices. This program cuts the variation in wheat and corn prices by 52 and 24 percent, respectively, but reduces fluctuations in livestock prices by only 4 percent. Finally, Arzac and Wilkinson (1979b) pick up Robinson's notion that stable feed prices alone are not enough to stabilize the livestock sector. Optimal control experiments on their model suggest that fluctuations in livestock prices can be reduced (though not eliminated) by countercyclical management of a combination of target prices for grains and import quotas for beef, but not by use of grain price or stock policies alone. 
Within the livestock sector, the effects of feed price volatility are concentrated in the beef subsector, according to two studies, and in the pork and poultry subsectors according to another. Breimyer (1954, p. 682) argues that stable feed prices mainly benefit producers who purchase feed, and that among these producers, hog and poultry feeders benefit more than cattle feeders. Offutt's model (1982) implies that beef, hog, and poultry prices are somewhat stabilized by consumers' willingness to substitute one for the other and by the different biological lags in their responses to corn price movements (which tend to prevent their supplies from expanding or contracting in unison). With these prices somewhat stable, feedlot oper $\mathrm{a}-$ tors stabilize their margins by bidding more for feeder calves when feed prices are low and vice versa. This has the effect of passing most of the variability in feed prices back into the price of feeder calves. (The same logic would seem to apply to feeder pig prices, but Offutt does not mention them.) Ray and Trapp (1977) disagree with Offutt's logic but still find that cow-calf producers bear the brunt of feed price volatility. They hold that volatile feed prices destabilize feedlot operators' margins, which leads to a contraction in beef feeding and reduced demand for feeder calves.

The Ray and Trapp study is one of the few I know of that goes beyond the examination of prices and quantities to discuss the effects of feed price volatility on livestock producers' gross or net income. Nonetheless, some inferences from other studies can be drawn indirectly.

One implication is that stable feed prices cut two ways [Breimyer (1954)]. On the one hand they remove a source of instability in livestock producers' income. On the other hand, by making rigid the price of an important input in livestock production they prevent livestock producers from passing the effects of nonfeed shocks (such as a fall in con- 
sumer income) back into the grain sector. In other words the livestock sector may face a smaller total amount of uncertainty, but it must bear a larger proportion of the remaining uncertainty.

Another implication comes from research on consumers' habits. Although the evidence is hard to read because of the masking effects of household inventories [Wohlgenant and Hahn (1982)] and other problems, several studies claim that consumers' previous consumption of meat is an important influence on their current consumption [Anderson and Wilkinson (1983), Breimyer and Rhodes (1975), Wohlgenant and Hahn (1982)]. If this is so, then grain and livestock producers may have a "mutuality of interests" [Breimyer and Rhodes (1975, p. 946)] in stabilizing feed costs in order to avoid periods of high meat prices that would reduce meat consumption not just temporarily but, through changes in consumers' habits, even after the period of high meat prices. However, the benefits of stimulating consumers' use of beef through short periods of low meat prices might also be lost.

Several layers of uncertainty surround any conclusions that might be drawn about the effects of feed price variability on the livestock sector. Evidence that the grain programs have stabilized feed prices since the 1960 s is weak at best. The evidence is contradictory on whether feed price stability, even if it were achieved, would stabilize livestock prices and quantities. Finally, very little evidence exists on whether stable feed prices would stabilize livestock producers' incomes.

Economists have limited evidence on claims that the grain programs restructured the livestock sector. Both the grain and the livestock sectors have changed markedly since World War II. The number of grain and livestock farms has declined sharply and the remaining farms 
have not just grown bigger but have also reorganized, adopting new technologies and shifting resources from some activities and parts of the country into others [Schertz, et al. (1979)]. Economists have of ten speculated on the role the grain programs played in helping or hindering this transformation. Some evidence suggests that the programs played at least a small role in shifting resources out of livestock production and into crop production. Whether they also played a significant role in promoting the trend away from mixed crop and livestock farms toward today's more specialized farms has also been debated. Many economists find this effect to be plausible, others are more skeptical; so far there is little evidence on which side is correct.

High and stable grain prices can affect the livestock sector not only by raising feed costs but also by giving farmers incentives to shift scarce farm resources-land, labor, and capital-from livestock and forage production to grain production. Although these effects have not received as much attention as the direct effects of feed prices, many studies suggest that they have been important in at least some parts of the country.

In the Great Plains states, where the allocation of land between pasture, for age, and grains or cotton can be quite sensitive to the expected returns from each, the grain (and cotton) programs may have tipped the balance toward crops and away from cattle pasture and forage. Houck and Ryan (1972), for example, note that a since-closed loophole in the acreage reduction programs of the 1950 s helped spread sorghum cultivation in the southern plains, and Ray and Trapp (1977) suggest that supported grain prices partly paid for irrigation systems that converted much arid land from range or part-time cropland to full-time cropland. The Disaster Payment Program, by providing free crop insurance even in droughty areas 
not normally cropped every year, had the same effect [Gardner (1978a, pp. 107-8)]. Also, farm planning models indicate the importance of grain prices and grain program requirements and benefits in determining the best uses of farm resources in the Great Plains [Krenz and Danielson; Whitson, Lacewell, and Shipley (1973) \}. Salathe, Price, and Banker (1984) estimate that the FORP increased production of wheat and barley, the predominant crops in much of the northern Great Plains, by 2-3 percent in 1979. Others have noted this effect, in the Great Plains and elsewhere [Breimyer (1954); Johnson and Clayton (1982, p. 954) ], although Shepherd et al. (1960, p. 7) claim that its impact on cattle production is small, and Gardner (1981a, p. 28) and Schertz and others (1979, pp. 97, 110) point out that the supply control component of the grain programs sometimes boosted cattle production by allowing grazing on land idled by the grain programs.

The risk of having too many eggs in one basket has always given farmers an incentive to retain the flexibility of shifting resources between crops and livestock, depending on which is more profitable. Since World War II, however, many farmers have decided to forgo the risk-reducing advantages of mixed crop and livestock farming and have specialized in one or the other. Some economists claim that this trend was significantly encouraged by grain programs that reduced the risks of specialized farming, especially in the early postwar period. They either make the general point that with less risk there was less incentive not to specialize [Penn (1976), Johnson et al. (1976), Gardner (1978a), Schertz and others (1979, pp. $112,241)]$, or elaborate a bit, arguing that stable margins and volumes in the beef, hog, and poultry feeding businesses made farmers more willing and able to raise capital for investments in specialized livestock-feeding facilities [Gustafson (1977), Roberts and Heady (1980), Ray and Trapp (1977)]. 
Other studies caution that although the hypothesis that stabilized grain prices promoted specialized farming is plausible, it has not been tested against alternative explanations. Among the other factors that may have promoted specialization were growing demands for fed beef and poultry [Roberts and Heady (1980), Gustafson (1977), Meisner and Rhodes (1974) ], changes in farm technology that led to increasing returns to scale in crop and livestock farming [Colyer and Irwin (1967), Roberts and Heady (1980), Furtan and Gray (1981), Meisner and Rhodes (1974), Schertz and others (1979, pp. 164, 240)], increased feed supplies in the Southwest (which were partly, but only partly, related to the grain programs [Meisner and Rhodes (1974)]), increased for age supplies in the Southeast (mostly for reasons unrelated to the commodity programs [Schertz, et al. (1979, p. 96) ]), and tax shelters [Breimyer (1978)]. Among all these other factors, risk may simply have been a very minor consideration in the specialization of agriculture. Without better evidence and better tests of this hypothesis than are now available, there is no way to tell [Gardner (1978b)].

\section{CONCLUSIONS}

At a very broad level, many economists agree about how the federal governments ${ }^{\dagger}$ grain programs have affected the livestock sector. Most accept that the programs raised average grain prices in the early $1980 \mathrm{~s}$, the 1960s, and, especially, the I950s. Most also accept that higher grain prices reduce livestock production and raise livestock prices and livestock producers' gross income.

Economists find much less common ground, however, over the extent of these effects and over the extent or even the direction of many other possible effects. Economists using different models that omit differ- 
ent details of the grain-livestock sector come up with different quantitative estimates of the effects of higher feed prices on the livestock sector generally and don't agree on which livestock subsectors are most helped or hurt by the grain programs. They also disagree about whether the grain programs ever have or ever could stabilize grain prices without raising them, and about whether stable grain prices significantly stabilize production, prices, and incomes in the livestock sector. What some economists apparently accept as clear-that the grain programs hastened the decline of mixed crop-livestock farms-others regard as dubious and untested. 
Anderson, Ronald, and Wilkinson, Maurice. "Consumer Welfare and the Livestock Economy in the United States." Canadian Journal of Agricultural Economics 31(3): 351-70. (1983)

Arzac, Enrique R., and Wilkinson, Maurice. "A Quarterly Econometric Model of United States Livestock and Feed Grain Markets and Some of Its Policy Implications." American Journal of Agricultural Economies $61(2)$ : 297-308. (1979a)

Arzac, Enrique R., and Wilkinson, Maurice. "Stabilization Policies for United States Feed Grain and Livestock Markets." Journal of Economic Dynamics and Control 1: 39-58. (1979b)

Bain, Robert A. "An Econometric Model of the Beef and Pork Sectors: Development and Application to Policy Analysis." Ph.D. dissertation, Cornell University. (1976)

Bancroft, Robert L. "An Econometric Analysis of Aggregate Acreage Response, Program Participation and Land Retirement." Ph.D. dissertation, Purdue University. (1981)

Bessler, David A. "An Analysis of Dynamic Economic Relationships: An Application to the U.S. Hog Market." Canadian Journal of Agricultural Economics 32: 109-24. (1984)

Brandow, George E. "Direct Payments Without Production Controls." Pages 65-74 in: Economic Policies for Agriculture in the 1960's; Implications of Four Selected Alternatives. U.S. Congress Joint Economic Committee, 86th Congress, 2d Session. U.S. Government Printing Office, Washington, DC. (1960)

Brandow, George E. "Interrelations Among Demands for Farm Products and Implications for Control of Market Supply." Pennsylvania Agricultural Experiment Station Bulletin 680, University Park. (1961)

Breimyer, Harold F. "Effect of Feed Price Stabilization Programs on Livestock." Journal of Farm Economics 36(4); 680-86. (1954)

Breimyer, Harold F. "Emerging Phenomenon: A Cycle in Hogs." Journal of Farm Economies 41(4): 760-8. (1959)

Breimyer, Harold F. "Agriculture's Three Economies in a Changing Resource Environment." American Journal of Agricultural Economics $60(1): 37-47 .(1978)$

Breimyer, Harold F., and Rhodes, V. James. "Livestock Aspects of Feed Grain Policy." American Journal of Agricultural Economies 57(5): 945-48. (1975)

Chavas, Jean-Paul. "A Quarterly Econometric Model of the U.S. Poultry and Egg Industry." Ph.D. dissertation, University of MissouriColumbia. (1978) 
Cochrane, Willard W., and Ryan, Mary E. American Farm Policy 19481973. University of Minnesota Press, Minneapolis. (1976)

Colyer, Dale, and Irwin, George D. "Beef, Pork, and Feed Grains in the Cornbelt: Supply Response and Resource Adjustments." Research Bulletin 921, University of Missouri, College of Agriculture, Agricultural Experiment Station, Columbia, MO. (1967)

Congressional Budget Office. "Ag Price Support Programs: A Layman's Guide." Special study, U.S. Congress. (1976)

Eckstein, Zvi. "A Rational Expectations Model of Agricultural Supply." Journal of Political Economy 92(1): 1-19. (1984)

Egbert, Alvin C., and Reutlinger, Shlomo. "A Dynamic Long-Run Model of the Livestock-Feed Sector." Journal of Farm Economics 47(5): 1288305. (1965)

Ericksen, Milton H., Ray, Daryll E., and Richardson, James W. "Farm Programs and Grain Reserves-Simulated Results." Pages 136-56 in: Analyses of Grain Reserves, A Proceedings. Compiled by David J. Eaton and W. Scott Steele. Economic Research Service Report No. 634, Economic Research Service, U.S. Department of Agriculture. (1976)

Folwell, Raymond J., and Shapouri, Hossein. "An Econometric Model of the U.S. Livestock and Broiler Sectors." Technical Bulletin 0094, College of Agriculture Research Center, Washington State University. (1980)

Freebairn, J. W., and Rausser, Gordon C. "Effects of Changes in the Level of U.S. Beef Imports." American Journal of Agricultural Economies 57(4): 676-88. (1975)

Furtan, W. Hartley, and Gray, Richard S. "The Translog Production Function: Application to Saskatchewan Agriculture." Canadian Journal of Agricultural Economics 29(1): 82-6. (1981)

Gardner, Bruce L. "The Farm-Retail Price Spread in a Competitive Food Industry." American Journal of Agricultural Economics 57(3): 399409. (1975)

Gardner, Bruce L. "Farm Policy and Research on Risk Management." Pages 100-12 in: Market Risks in Agriculture: Concepts, Methods and Policy Issues. Departmental Technical Report No. 78-l, Department of Agricultural Economics, Texas Agricultural Experiment Station, Texas A\&M University, College Station. (1978a)

Gardner, Bruce L. "Public Policy and the Control of Agricultural Production." American Journal of Agricultural Economics 60(5): 836-43. (1978b)

Gardner, Bruce L. Optimal Stockpiling of Grain. Lexington Books, Lexington, MA. (1979) 
Gardner, Bruce L. The Governing of Agriculture. The Regents Press of Kansas, Lawrence. (1981a)

Gardner, Bruce L. Consequences of USDA's Farmer-Owned Reserve Program for Grain Stocks and Prices. Volume 2 of Farmer-Owned Grain Reserve Program Needs Modification to Improve Effectiveness. CED81-70; General Accounting Office. (1981b)

Gustafson, Ronald A. "Livestock-Grain Interdependence: Implications for Policy." Pages 119-29 in: Agricultural-Food Policy Review. ERS AFPR-1, Economic Research Service, U.S. Department of Agriculture. (1977)

Hallam, J. Arne. "A Dynamic Equilibrium Analysis of Agricultural Stabilization Policy." Ph.D. dissertation, University of California, Berkeley. (1983)

Hathaway, Dale E. "Government and Agriculture Revisited: A Review of Two Decades of Change." American Journal of Agricultural Economies 63(5): 779-87. (1981)

Heien, Dale. "An Econometric Model of the U.S. Pork Economy." The Review of Economics and Statisties 57: 370-375. (1975)

Heien, Dale. "An Economic Analysis of the U.S. Poultry Sector." American Journal of Agricultural Economics 58: 311-316. (1976)

Houck, J. P. "The Short-Run Impact of Beef Imports on U.S. Meat Prices." Australian Journal of Agricultural Economies 18(1): 60-72. (1974)

Houck, J. P., and Ryan, M. E. "Supply Analysis for Corn in the United States: The Impact of Changing Government Programs." American Journal of Agricultural Economies 54: 184-91. (1972)

Johnson, Jemes, and Clayton, Kenneth. "Organization and Well-Being of the Farming Industry: Reflections on the Agriculture and Food Act of 1981." American Journal of Agricultural Economics 64(5): 947-56. (1982)

Johnson, James D., Ericksen, Milton H., Sharples, Jerry A., and Harrington, David H. "Price and Income Policies and the Structure of Agriculture." Pages 174-84 in: Structure Issues of American Agriculture. U.S. Department of Agriculture; Economics, Statistics, and Cooperatives Service; Agricultural Economic Report 438. (1979)

Just, Richard E. Theoretical and Empirical Considerations in Agricultural Buffer Stock Policy Under the Food and Agricultural Act of 1977. Volume 3 of Farmer-Owned Grain Reserve Program Needs Modification to Improve Effectiveness. CED-81-70; General Accounting office. (1981)

Krenz, Ronald D., and Danielson, Bernard G. "Beef vs Wheat Production in South Central North Dakota." Department of Agricultural Economics, North Dakota State University, Fargo. 
Lucas, Robert E., Jr. "Econometric Policy Evaluation: A Critique." Pages 19-46 in: The Phillips Curve and Labor Markets. Karl Brunner and Allan H. Meltzer, eds. North-Holland Publishing Co., Amsterdam. (1976) Reprinted in: Studies in Business-Cycle Theory, pp. 104-130. Robert E. Lucas, Jr. The MIT Press, Cambridge, MA. (1981)

Lucas, Robert E., Jr., and Sargent, Thomas J. "Introduction." Pages xi-xl in: Rational Expectations and Econometric Practice, Vol. 1. Robert E. Lucas, Jr. and Thomas J. Sargent, eds. The University of Minnesota Press, Minneapolis. (1981)

Marsh, John M. "A Rational Distributed Lag Model of Quarterly Live Cattle Prices." American Journal of Agricultural Economics 65(3): 539-47. (1983)

Martin, Larry J., and Haack, Richard. "Beef Supply Response in North America." Canadian Journal of Agricultural Economics 25(3): 29-47. (1977)

Martin, Larry, and Zwart, Anthony C. "A Spatial and Temporal Model of the North American Pork Sector for the Evaluation of Policy Alternatives." American Journal of Agricultural Economics 57(1): 55-66. (1975)

Martin, W. J., and Heady, Earl O. "A Quarterly Model of the U.S. Livestock-Feed Subsector and Some of Its Dynamic Multipliers." CARD Report $127 \mathrm{~T}$, Center for Agricultural and Rural Development, Iowa State University, Ames. (1984)

Meisner, Joseph C., and Rhodes, V. James. "The Changing Structure of Cattle Feeding." University of Missouri Special Report 167. (1974)

Meyers, William H., and Ryan, Mary E. "The Farmer-Owned Reserve: How Is the Experiment Working?" American Journal of Agricultural Economics $63(2)$ : $316-23$. (1981)

Morton, Andrew S., Devadoss, S, and Heady, Earl O. "Potential Grain Price Instability Under Alternative Farm Policies." CARD Report 129, Center for Agricultural and Rural Development, Iowa State University, Ames. (1984)

Muth, John F. "Rational Expectations and the Theory of Price Movements." Econometrica 29(3): 315-335. (1961)

NeIson, Frederick James. "An Economic Analysis of the Impact of Past Farm Programs on Livestock and Crop Prices, Production, and Resource Adjustments." Ph.D. thesis, University of Minnesota. (I975)

Offutt, Susan E. "The Impact of Export Instability on the U.S. Corn and Livestock Markets: An Econometric Analysis." A.E. Res. 82-45, Department of Agricultural Economics, Cornell University Agricultural Experiment Station, Ithaca, NY. (1982)

Ospina, Enrique, and Shumway, C. Richard. "Impact of Corn Prices on Slaughter Beef Composition and Prices." American Journal of Agricultural Economies 63(4): 700-3. (1981) 
Penn, J. B. "The Structure of Agriculture: An Overview of the Issue." Pages 2-23 in: Structure Issues of American Agriculture. U.S. Department of Agriculture; Economics, Statistics, and Cooperatives Service; Agricultural Economic Report 438. (1979)

Prindle, Allen M. "Impact on Livestock Producers of U.S. Policies Affecting Feed Supplies." Journal of the Northeastern Agricultural Economics Council 8(1): 289-98. (1979)

Rasmussen, Wayne D., and Baker, Gladys L. "Price-Support and Adjustment Programs from 1933 Through 1978: A Short History." U.S. Department of Agriculture; Economics, Statistics, and Cooperatives Service; Agriculture Information Bulletin No. 424. (1979)

Ray, Daryll E., and Heady, Earl O. "Simulated Effects of Alternative Policy and Economic Environments on U.S. Agriculture." CARD Report 46T, Center for Agricultural and Rural Development, Iowa State University, Ames. (1974)

Ray, Daryll E., and Trapp, James N. "Grain-Livestock Interrelations and Tradeoffs with Implications for the Structure of the Livestock Industry." Pages 25-49 in: Farm and Food Policy Symposium. Proceedings of a symposium on agricultural policy held Feb. 22-24, 1977, Kansas City, MO. Great Plains Agricultural Council, Publication No. 84. (1 984)

Reutlinger, Shlomo. "Analysis of a Dynamic Model, with Particular Emphasis on Long-Run Projections." Journal of Farm Economies 48(1): 88106. (1966)

Roberts, Roland K., and Heady, Earl O. "An Analysis of Selected Agriculture Policy Impacts on the U.S. Livestock Sector by an Econometric Simulation Model." CARD Report 92, Center for Agricultural and Rural Development, Iowa State University, Ames. (1980)

Robinson, Kenneth L. "The Impact of Government Price and Income Programs on Income Distribution in Agriculture." Journal of Farm Economies 47(5): 1225-34. (1965)

Robinson, K. L. "Unstable Farm Prices: Economic Consequences and Policy Options." American Journal of Agricultural Economics 57(5): 769-77. (1975)

Ryan, Timothy J. "A Note on Bias in the Estimated Effects of Beef Imports on U.S. Meat Prices." Australian Journal of Agricultural Economics 24(1): 60-4. (1980)

Salathe, Larry, and Price, J. Michael. "The Impacts of the 1983 Drought on the U.S. Beef Cattle Industry." Manuscript.

Salathe, Larry, Price, J. Michael, and Banker, David E. "An Analysis of the Farmer-Owned Reserve Program, 1977-82." American Journal of Agricultural Economies 66(1): 1-11. (1984) 
Salathe, Larry E., Price, J. Michael, and Gadson, Kenneth E. "The Response of the Hog Industry to a Reduction in Corn Production: An Application of the Food and Agricultural Policy Simulator." North Central Journal of Agricultural Economics 5(2): 139-46. (1983)

Schertz, Lyle P, and others. "Another Revolution in U.S. Farming?" U.S. Department of Agriculture; Economics, Statisties and Cooperatives Service; Agricultural Economic Report No. 441. (1979)

Sheffrin, Steven M. Rational Expectations. Cambridge University Press, Cambridge. (1983)

Shepherd, Geof frey, Paulsen, Arnold, Kutish, Francis, Kaldor, Don, Heifner, Richard, and Futrell, Gene. "Production, Price and Income Estimates and Projections for the Feed-Livestock Economy Under Specified Control and Market-Clearing Conditions." Special Report No. 27, Department of Economies and Sociology, Center for Agricultural and Economic Adjustment, Agricultural and Home Economics Experiment Station, lowa State University of Science and Technology, Ames. (1960)

Shonkwiler, J. Scott, and Spreen, Thomas H. "A Dynamic Regression Model of the U.S. Hog Market." Canadian Journal of Agricultural Economics 30(1): $37-48$. (1982)

Simmons, Will M., and Rizek, Robert L. "Performance of the LivestockFeed-Grain Sector." Journal of Farm Economics 48(5): 1455-63. (1966)

Sims, Christopher A. "Macroeconomics and Reality." Econometrica 48: 1-48. (1980)

Sims, C. "Policy with Econometric Models." Brookings Papers on Economic Activity 1: 107-64. (1982)

Spathis, Paul. "The Impact of Fluctuating Grain and Soybean Prices on Livestock Producers and Consumers in the U.S." A.E. Res. 83-6, Department of Agricultural Economics, Cornell University Agricultural Experiment Station, Ithaca, NY. (1983)

Stein, John Picard, and Smith, Rodney Topper. The Economics of United States Grain Stockpiling. R-1861-CIEP. The Rand Corporation. (1977)

Teigen, Lloyd D., Bell, Thomas M., and Roop, Joseph M. "An Analysis of the 1979 Feed Grain Set-Aside Program." Agricultural Economics Research 32(1): 45-50. (1980)

Todd, Richard Michael. "A Dynamic Equilibrium Model of Seasonal and Cyclical Fluctuations in the Corn-Soybean-Hog Sector." Ph.D. thesis, University of Minnesota. (1983)

Tweeten, Luther G. "Commodity Programs for Agriculture: A Review of Economic Studies." Pages 109-30 in: Agricultural Policy: A Review of Programs and Needs. Volume V, Technical Papers, National Advisory Commission on Food and Fiber. (1967) 
Walker, Rodney L., Sharples, Jerry A., and Holland, Forrest. "Grain Reserves for Feed Grains and Wheat in the World Grain Market." Pages 114-35 in: Analyses of Grain Reserves, A Proceedings. Compiled by David J. Eaton and W. Scott Steele. Economic Research Service Report No. 634, Economic Research Service, U.S. Department of Agriculture. (1976)

Whitson, Robert E., Lacewell, Ronald D., and Shipley, John. "Economic Analysis of Irrigated Wheat and Stocker Grazing Alternatives in the Northern High Plains of Texas and Oklahoma." Texas Agricultural Experiment Station, Department of Agricultural Economics, Departmental Technical Report 73-3. (1973)

Wohlgenant, Michael K., and Hahn, William F. "Dynamic Adjustment in Monthly Consumer Demands for Meats." American Journal of Agricultural Economics 64(3): 553-7. (1982) 